\title{
Digestibility of Soybean Cake, Niger Seed Cake and Linseed Cake in Juvenile Nile Tilapia, Oreochromis niloticus L.
}

\author{
Akewake Geremew ${ }^{1 *}$, Abebe Getahun ${ }^{2}$ and Krishen Rana ${ }^{3}$ \\ ${ }^{1}$ Department of Biology, Dilla University, P. O. Box 419, Dilla, Ethiopia \\ ${ }^{2}$ Department of Zoological Sciences, Addis Ababa University, P. O. Box 1176, Addis Ababa, Ethiopia \\ ${ }^{3}$ Department of Sustainable Aquaculture, Stellenbosch University, Stellenbosch, South Africa
}

\begin{abstract}
The apparent digestibility coefficients (ADCs) of dry matter, protein, lipid and energy for soybean cake (SBC), Niger seed cake (NSC) and linseed cake (LSC) were determined in juvenile Nile tilapia. The ADCs were determined using faeces collected with a settling chamber attached to the fish rearing tank. Test diets contained $70 \%$ reference diet and $30 \%$ test ingredients, with $\mathrm{Cr}_{2} \mathrm{O}_{3}$ as an inert marker. All treatments were triplicated. There was significant difference in Apparent Dry Matter Digestibility (ADMD), Apparent Protein Digestibility (APD) and Apparent Energy Digestibility (AED) between the test ingredients. However, there was no significant difference $(P>0.05)$ in Apparent Lipid Digestibility (ALD) between the test ingredients. Of the three ingredients tested, SBC produced the highest nutrient digestibility coefficients $(P<0.05)$ while LSC showed the lowest nutrient digestibilities $(P<0.05)$. The NSC, which was the cheapest plant protein source, was a good feed ingredient for Nile tilapia diets in terms of overall nutrient composition and acceptable digestibility coefficients enabling more accurate and economical feed formulation.
\end{abstract}

Keywords: Juvenile nutrition; Plant proteins; African aquaculture; Fish meal; Ethiopian oilseeds

\section{Introduction}

With the increase in intensive aquaculture, demand for more efficient aquafeed is rising. Feed comprises the principal operating cost in fish production and the main protein source has traditionally been fish meal [1]. Fishmeal, the conventional protein source in aquaculture feeds, supports good fish growth because of its protein quality and palatability [2]. However, fish meal is often scarce and expensive, due to limited availability and high demand, which often leads to high fish production costs [3,4]. According to Ng and Romano [2], cost-effective, practical aquaculture feeds can be produced without the use of fish meal with no resulting or apparent loss in fish growth in some species. Hence, replacing fish meal with cheaper ingredients of either animal origin or protein-rich plant sources is a necessary priority for nutrition research $[1,2]$. In view of this, oilseed meals have been found to have considerable economic potential $[2,5]$. While grain legumes have not been widely used within aquaculture feeds, oilseeds and their byproducts frequently constitute a major source of dietary protein within aquaculture feeds for warm water fish species such as those commonly used in African aquaculture, including tilapias (Oreochromis spp.) and African catfish [6].

A feed ingredient may appear from its chemical composition to be an excellent source of nutrients but will be of little actual value unless it can be ingested, digested and absorbed in the target species. Only a proportion of ingested food is digested and its nutrients absorbed, the rest is voided as faeces. By definition, digestibility is a relative measure of the extent to which ingested food and its nutrient components have been digested and absorbed by the animal. Knowledge of nutrient digestibility is, therefore, important to establish the potential of an ingredient for use in diets of aquaculture species [2,7]. Determining the digestibility of nutrients in feedstuffs is important not only to enable formulation of diets that maximize the growth of cultured species, by providing appropriate amounts of available nutrients, but also to limit the wastes produced by the fish and reduce costs $[1,2,7,8]$.

For tilapia feeds typical protein sources examined have included cereal grain products [9], defatted soybean meal, full-fat toasted soybean, lupin seed meal and faba bean meal [10], cottonseed meal, sunflower meal [11], fish and poultry meals, corn gluten, rapeseed meal, sorghum, barley [12], anchovy meal, corn gluten meal, soybean meal, gammaridmeal and crayfish exoskeleton meal [13]. Among the plant protein sources, soybean meal has been used most widely because it has a good amino acid profile, which, as the main source of protein, supports fish growth [14]. Soybeans, however, are not grown widely in Ethiopia; hence there is a need to evaluate soybeans together with other more locally available plant proteins. According to Lovell [15] feed ingredients containing $20 \%$ or more crude protein are considered protein sources. In the present study soybean cake (SBC), linseed cake (LSC) and Nigerseed cake (NSC) were selected as dietary protein sources on the basis of their high protein content, availability and use in animal feeds for Ethiopia. Studies conducted on SBC, LSC and NSC showed they have good protein contents (30-40\%), depending on processing methods $[16,17]$.

Niger seed is the most important oil crop of Ethiopia, providing $50-60 \%$ of the country's indigenous edible oil. It is also minor oil crop in India, Kenya, Uganda, Sudan, Malawi and other African and Indian sub-continent countries. Its seeds are inexpensive to process, and the cake remaining after oil extraction is used as a protein supplement in animal diets [16]. Niger seed cake contains few or no known antinutritional factors [18].

Ethiopia ranks among the top five world producers of linseed and it is the second most important oil crop in the country next to Niger seed [19]. The usefulness of linseed as an ingredient in the diets of fish has been studied by different authors [20-23]. Nutrient and energy

*Corresponding author: Akewake Geremew, Dilla University, Department of Biology, P.O.Box 419, Dilla, Ethiopia, Tel: 251911814040; E-mail: khaliger@yahoo.com

Received March 05, 2015; Accepted March 10, 2015; Published April 15, 2015

Citation: Geremew A, Getahun A, Rana K (2015) Digestibility of Soybean Cake, Niger Seed Cake and Linseed Cake in Juvenile Nile Tilapia, Oreochromis niloticus L. J Aquac Res Development 6: 333. doi:10.4172/2155-9546.1000333

Copyright: (C) 2015 Geremew A, et al. This is an open-access article distributed under the terms of the Creative Commons Attribution License, which permits unrestricted use, distribution, and reproduction in any medium, provided the original author and source are credited. 
digestibility studies have been conducted more extensively on soybean for many fish species than on LSC. However, digestibility of NSC in fish diets has not been researched into at all, probably because it is restricted to Eastern Africa, mainly Ethiopia.

This study was conducted to evaluate the apparent digestibility coefficients (ADCs) of dry matter (DM), crude protein (CP) and gross energy (GE) for SBC, LSC and NSC for Nile tilapia, O. niloticus.

\section{Materials and Methods}

Fingerlings of Nile tilapia of Lake Hora origin with an average weight of $8.9 \pm 1.6 \mathrm{~g}$ were stocked at 10 fish per tank (60 l tanks) in a water recirculation system established at Ziway Fisheries Resources Research Center by Addis Ababa University Department of Zoological Sciences. All treatments were conducted in triplicate. Fish were fed by hand, twice a day (10:00, 16:00 hours) at a rate of $6 \%$ body weight per day. The experiment took 2-3 weeks. The recirculation system was supplied with aerated water from a sump tank thermoregulated at $28 \pm 1^{\circ} \mathrm{C}$ and a constant photoperiod of 12 hours light/12 hours darkness was maintained. Water quality parameters measured during the experiment averaged $( \pm \mathrm{SD})$ : temperature, $28.9 \pm 0.4^{\circ} \mathrm{C} ; \mathrm{pH}, 7.3 \pm$ 0.1 ; ammonia, $0.17 \pm 0.08 \mathrm{mg} \mathrm{l}^{-1}$; nitrite, $0.20 \pm 0.1 \mathrm{mg} \mathrm{l}^{-1}$; Nitrate, $50 \pm$ $23.2 \mathrm{mg} \mathrm{l}^{-1}$ and dissolved oxygen, $5.4 \pm 0.4 \mathrm{mg} \mathrm{l}^{-1}$ and they were within acceptable ranges for tilapia.

\section{Diet Formulation}

A reference diet (Table 1) was formulated to satisfy the nutrient requirements of Nile tilapia [24]. It contained $320 \mathrm{~g} \mathrm{~kg}^{-1}$ crude protein, $100 \mathrm{~g} \mathrm{~kg}^{-1}$ lipid and $18 \mathrm{kJg}^{-1}$. The test ingredients for apparent digestibility were soybean cake (SBC), linseed cake (LSC) and Nigerseed cake (NSC). All test feed ingredients were obtained from commercial sources in Ziway, Ethiopia with the exception of soybean cake which was acquired from Addis Ababa oil processing factory outlet.

Three test diets were formulated using $70 \%$ reference diet and $30 \%$ of each of the test ingredients as described by Cho et al. [25]. This method assumes that there are no interactions among the components of the diet during digestion [26]. Chromic oxide was used as an inert marker at a concentration of $0.5 \%$ in the diets. Other supplements used in the diet are indicated in Table 1.

\section{Diet preparation}

Fishmeal was processed from waste obtained from a local fish processing plant known as "ZiwayFish Processing Plant". The filleting residues were purchased from the processing plant at a price of 0.15 birr $\mathrm{kg}^{-1}$. The freshly collected filleting residues of tilapia were minced using an electrical meat mincer and then dried in an oven for 48 hours at $75^{\circ} \mathrm{C}$. The dried residue was ground into a fine powder using an electrical smashing machine, sieved $(0.5 \mathrm{~mm}$ mesh size sieve $)$ and then stored in a plastic bag at $-18^{\circ} \mathrm{C}$ in a deep freeze.

The diets were formulated on as anfed basis. Fish meal as the main dietary protein source and wheat and corn grains (milled) as main carbohydrate sources were used in the experiment. A poultry grade vitamin/mineral premix (Table 1) at $50 \mathrm{~g} \mathrm{~kg}^{-1}$ and a binder (carboxymethyl cellulose, high viscosity) at $20 \mathrm{~g} \mathrm{~kg}^{-1}$ were added. The vitamin/mineral premix was purchased from the local market in Addis Ababa. This premix is prepared for egg laying hens by an Israeli company called Koffolk Animal Health and Nutrition. Soybean oil was used as the source of lipid in the diets. Chromic oxide was added as an indigestible marker for digestibility study [27].
Diets were prepared by wet extrusion using a meat mincer (Model TJ 22). All ingredients were finely ground and sieved through a 500 $\mu \mathrm{m}$ sieve to obtain a homogenous mixture. The dry ingredients were then weighed out according to the formulation, placed in an aluminum bowl and mixed until uniformly blended using a modified mixer. The resulting homogenate was moistened after addition of water $(20 \%$ $30 \%$ ) slowly with continuous stirring until a dough was formed before passing through an electrical meat mincer with a $2.5 \mathrm{~mm}$ die. The expelled strands produced from meat mincer were dried in an oven with a convector fan at $35-40^{\circ} \mathrm{C}$ for 24 hours. They were then crushed in to crumbles and sieved with $1 \mathrm{~mm}$ mesh size sieve. The resulting pellets were packaged in polythene bags and stored in a deep freeze at $-18^{\circ} \mathrm{C}$. Prepared diet samples were analyzed for proximate composition, energy and chromic oxide.

\section{Faecal collection system}

In this study a settling column system was employed for faeces collection, but it was adapted to the $60 \mathrm{l}$ cylindrical tanks used. This collection system employed pipes fitted to the bottom of the rearing tanks with a vertical column and transparent hoses connected to a valve system at the bottom ends, where the faeces were deposited after settling. At the top end of the vertical column an overflow was provided to get rid of excess water flowing through the system. Deposited faeces were collected by opening the valve at the tip end and carefully draining the faeces into centrifuge bottles. The collectors were fixed to the rearing tanks the night before and faeces collected early the next morning. Faeces were immediately centrifuged at $4,300 \times \mathrm{g}$ for $10 \mathrm{~min}$ and the supernatant discarded. Wet settled solids of faeces were frozen at $-20^{\circ} \mathrm{C}$ to retard bacterial decomposition. Faecal samples were later defrosted and oven dried at $60^{\circ} \mathrm{C}$, ground and analyzed for crude protein (CP), crude lipid (CL), gross energy (GE) and chromic oxide contents.

\section{Analytical techniques}

Ingredients, diets and faeces were analyzed in triplicates for proximate composition according to standard methods [28], and chromic oxide of diets and faeces analyzed by acid digestion with molybdate reagent followed by DPC (Diphenylcarbazide) colorimetry following the procedure in Divakaran et al. [27]. Energy was determined using an Adiabatic Autobomb Calorimeter with benzoic acid as a standard.

The apparent digestibility coefficients (ADC) for the nutrients of the diets were calculated as follows [29]:

\begin{tabular}{|c|c|c|}
\hline Ingredients & Reference diet & Test diets \\
\hline Test ingredient & - & 298.5 \\
\hline Fish waste meal & 407.6 & 285.3 \\
\hline Soybean meal & 100 & 70 \\
\hline Wheat grain & 20 & 14 \\
\hline Corn grain & 392.4 & 274.7 \\
\hline Soybean oil & 5.0 & 3.5 \\
\hline Vitamin mineral premix & 50 & 35 \\
\hline Carboxymethyl cellulose & 20 & 14 \\
\hline Chromic oxide & 5.0 & 5.0 \\
\hline
\end{tabular}

${ }^{1}$ Vitamin mineral premix (providing per $\mathrm{kg}$ ): vitamin A (retinol), $14000 \mathrm{mg}$; vitamin $\mathrm{D}_{3}$ (chole-calciferol), $4000 \mathrm{mg}$; vitamin $\mathrm{E}$ (tocopheryl acetate), $10000 \mathrm{I} . \mathrm{U}$; vitamin $\mathrm{K}_{3}$, $2000 \mathrm{mg}$; thiamine, $1000 \mathrm{mg}$; riboflavin, $4000 \mathrm{mg}$; niacin, $10000 \mathrm{mg}$; pantothenic acid, $5000 \mathrm{mg}$; pyridoxine, $750 \mathrm{mg}$; folic acid, $250 \mathrm{mg}$; vitamin B12, $8 \mathrm{mg}$; vitamin $\mathrm{H}$ as Biotin, $30 \mathrm{mg}$; betain, $100000 \mathrm{mg}$; Antioxidant, $125000 \mathrm{mg}$. Minerals: Manganese, $80000 \mathrm{mg}$; Zinc, 50000 mg; Iron, 20000 mg; Copper, 5000 mg; lodine, $1200 \mathrm{mg}$; Cobalt, $200 \mathrm{mg}$; Selenium, $200 \mathrm{mg}$.

Table 1: Composition of reference and test diets $\left(\mathrm{g} \mathrm{kg}^{-1}\right)$ for the digestibility study 


$$
A D C=100 \times\left[1-\left(\frac{F}{D}\right) \times\left(\frac{D_{i}}{F_{i}}\right)\right]
$$

Where $\mathrm{D}=\%$ nutrient of diet; $\mathrm{F}=\%$ nutrient of faeces; $\mathrm{Di}=\% \mathrm{Cr}_{2} \mathrm{O}_{3}$ of diet; $\mathrm{F}_{\mathrm{i}}=\% \mathrm{Cr}_{2} \mathrm{O}_{3}$ of faeces and $\mathrm{ADC}$ of ingredients as,

$$
A D C_{\text {testingredient }}=A D C_{\text {test diet }}+\left[\left(A D C_{\text {testdiet }}-A D C_{\text {ref.diet }}\right)\left(\frac{0.7 \times D_{\text {ref }}}{0.3 \times D_{\text {ingr }}}\right)\right]
$$

Where $\mathrm{D}_{\text {ref }}=\%$ nutrient (or $\mathrm{kJg}^{-1}$ gross energy) of reference diet (as fed); $D_{\text {ingr }}=\%$ nutrient (or kJg ${ }^{-1}$ gross energy) of test ingredient (as fed).

Digestible protein and energy were calculated as follows:

Digestible protein $\left(\mathrm{DP}, \mathrm{gkg}^{-1}\right)=$ dietary crude protein $\left(\mathrm{gkg}^{-1}\right.$, dry weight basis) $\times \mathrm{ADC}_{\text {protein }}$

Digestible energy $\left(\mathrm{DE}, \mathrm{kJg}^{-1}\right)=$ gross energy $\left(\mathrm{kJg}^{-1}\right.$, dry weight basis $)$ $\times \mathrm{ADC}_{\text {energy }}$

Statistical analyses in this study were conducted using Minitab Statistical Package (Version 15.0). Differences among dietary treatment means were tested by analysis of variance (ANOVA), and means compared using Tukey's Multiple Comparison Test to test for significance of variation between the means and differences were considered significant at $\mathrm{p}<0.05$. All percentages were arcsine transformed before analysis [30].

\section{Results}

\section{Chemical composition and prices of ingredients}

Proximate composition and energy contents of the ingredients used in the study are given in Table 2. Crude protein for oilseed cakes ranged from 310 to $393.8 \mathrm{~g} \mathrm{~kg}^{-1}$ with SBC the highest and LSC the lowest. In contrast, crude lipid was highest for LSC $\left(108.2 \mathrm{~g} \mathrm{~kg}^{-1}\right)$ and lowest for SBC $\left(74.4 \mathrm{~g} \mathrm{~kg}^{-1}\right)$. NSC had the highest crude fibre $(201.1 \mathrm{~g}$ $\left.\mathrm{kg}^{-1}\right)$ level, about three times higher than SBC which had the lowest fibre content $\left(64.8 \mathrm{~g} \mathrm{~kg}^{-1}\right)$. Gross energy values for ingredients ranged from 17.8 to $21.8 \mathrm{~kJ} \mathrm{~g}^{-1}$.

The prices of ingredients used in the study are shown in Table 2. Fish meal was the least expensive $\left(0.5\right.$ birr $\left.\mathrm{kg}^{-1}\right)$ ingredient as the cost for it is directly converted from the cost of fresh offal (0.15 birr $\left.\mathrm{kg}^{-1}\right)$ and $3.33 \mathrm{~kg}$ of offal dried in an oven can make approximately 1 $\mathrm{kg}$ of dried fishmeal. SBC and wheat grain were the most expensive ingredients, about double the price $\left(4 \mathrm{birr} \mathrm{kg}^{-1}\right)$ of NSC which was the least expensive among the oilseed cakes.

\section{Chemical composition of test diets}

Proximate and energy compositions of the reference and test diets used in the digestibility study are presented in Table 3 . Analyzed crude protein, crude lipid, NFE, dry matter, ash and energy contents of test diets showed little variation. However, crude fibre contents of diets varied considerably. Crude fibre of test diets followed similar trend as the test ingredients. Energy contents of the diets ranged between 18.6 and $18.9 \mathrm{~kJ} \mathrm{~g}^{-1}$.

\section{Nutrient and energy digestibility}

Apparent digestibility coefficients (ADCs) of protein, lipid, dry matter and energy in selected test ingredients for Nile tilapia are shown in Table 4. The results indicate that ADCs of the nutrients and energy studied were significantly different between the test ingredients except for crude lipid digestibility. Generally SBC had the highest ADC coefficients followed by NSC with LSC having the least ADC for energy and nutrients.

\section{Discussion}

The suitability of three oilseed by-products (SBC, NSC and LSC) available in Ethiopia were evaluated for their proximate composition and ADC values with the aim of providing information that aids improved formulation of balanced diets for Nile tilapia. The ADC values for dry matter, protein and energy were significantly different between the three test ingredients. However, lipid digestibility was not significantly different between the test ingredients.

In this study the test ingredients used had a high crude protein content and their values were close to previously reported values by Assaminew et al. [17], except for relatively higher crude protein $(32.4 \%$ Vs $28.1 \%)$ and lower crude fibre (25.3\% Vs $20.1 \%)$ values reported for Niger seed cake in this study. This variation between nutrient compositions of NSC could be due to differences in the origin, state and processing methods used to produce the cakes. The high crude fibre content of Nigerseed cake could limit the inclusion of this ingredient at higher levels in the diets of fish. It has been reported that dietary fibre is not utilized by fish [2].

The digestibility of ingredients provides insight concerning nutrient utilization and should enable better ingredient substitutions in diets designed for target species. The nutrient digestibility will vary depending on the composition of ingredients used $[2,8]$. The results of this study showed that ADC for dry matter, crude protein and energy in test ingredients were affected by test ingredients. These differences can be explained by the differences in chemical composition, origin and processing of these feed ingredients. The results of the present study indicated that Nile tilapia fingerlings have the capacity to digest protein and lipid satisfactorily in the oilseed by-product ingredients tested.

The overall dry matter digestibility of the test ingredients in the present study ranging from $59 \%$ to $78 \%$ is in the range reported for

\begin{tabular}{|c|c|c|c|c|c|c|c|c|}
\hline Ingredients & DM & CP & CL & CF & Ash & NFE & GE & Price \\
\hline Linseed cake & 908.8 & 310 & 108.2 & 136.3 & 82.7 & 233.4 & 18.6 & 7.5 \\
\hline Niger seed cake & 928 & 324.2 & 92 & 201.1 & 90.7 & 220 & 18.1 & 4.0 \\
\hline Soybean cake & 938 & 393.8 & 74.7 & 64.8 & 54 & 350.7 & 19.3 & 9.0 \\
\hline Fish waste meal & 950 & 610.9 & 187.1 & 0 & 220.4 & 0 & 21.8 & 0.5 \\
\hline Wheat grain & 875 & 96 & 16.54 & 57.9 & 13.6 & 690.9 & 17.9 & 8.0 \\
\hline Corn grain & 882.9 & 78.1 & 42.6 & 27.1 & 13.0 & 722.2 & 19.0 & 5.0 \\
\hline
\end{tabular}

*DM (dry matter), CP (crude protein), CL (crude lipid), NFE (nitrogen free extract) and GE (gross energy).

Table 2: Proximate composition ( $\mathrm{g} \mathrm{kg}^{-1}$ as fed), energy $\left(\mathrm{kJ} \mathrm{g}^{-1}\right)$ and prices (birr kg-1) of individual feed ingredients used in this study.

\begin{tabular}{|c|c|c|c|c|}
\hline Components & $\begin{array}{c}\text { Reference } \\
\text { diet }\end{array}$ & SBC & NSC & LSC \\
\hline Dry matter & 922.8 & 927.8 & 924.6 & 918.9 \\
\hline Crude protein & 321.0 & 341.0 & 320.3 & 316.1 \\
\hline Crude lipid & 105.8 & 96.0 & 101.1 & 106.0 \\
\hline Crude fibre & 18.6 & 32.2 & 72.8 & 53.5 \\
\hline Ash & 126.1 & 98.8 & 109.8 & 107.4 \\
\hline NFE & 351.5 & 359.5 & 320.6 & 336.0 \\
\hline Chromic oxide & 5.2 & 4.8 & 4.7 & 4.9 \\
\hline Gross energy $\left(\mathrm{kJ} \mathrm{g}^{-1}\right)$ & 18.9 & 18.9 & 18.6 & 18.7 \\
\hline
\end{tabular}

${ }^{*} \mathrm{SBC}=$ soybean cake, NSC= Niger seed cake, LSC = linseed cake

Table 3: Proximate composition $\left(\mathrm{g} \mathrm{kg}^{-1}\right)$ and energy of reference and test diets 


\begin{tabular}{|c|c|c|c|}
\hline Components & Soybean & Niger seed & Linseed \\
\hline Dry matter & $78.0 \pm 2.6^{\mathrm{a}}$ & $70.7 \pm 3.0^{\mathrm{b}}$ & $59.0 \pm 0.5^{\mathrm{c}}$ \\
\hline Crude protein & $87.9 \pm 3.2^{\mathrm{a}}$ & $72.6 \pm 2.0^{\mathrm{b}}$ & $62.4 \pm 4.2^{\mathrm{c}}$ \\
\hline Crude lipid & $81.4 \pm 2.2^{\mathrm{a}}$ & $78.9 \pm 2.8^{\mathrm{a}}$ & $79.4 \pm 3.0^{\mathrm{a}}$ \\
\hline Gross energy $\left(\mathrm{kJ} \mathrm{g}^{-1}\right)$ & $86.0 \pm 2.5^{\mathrm{a}}$ & $72.9 \pm 1.8^{\mathrm{b}}$ & $53.7 \pm 3.5^{\mathrm{c}}$ \\
\hline Digestible protein & 36.9 & 25.3 & 21.3 \\
\hline Digestible energy & 17.7 & 14.2 & 11.0 \\
\hline
\end{tabular}

Table 4: Apparent digestibility coefficients (\%) of protein, lipid, dry matter, energy and digestible protein and energy $\left(\mathrm{g} \mathrm{kg}^{-1}\right.$ and $\mathrm{kJ} \mathrm{g}^{-1}$ respectively, dry weight basis) in the test ingredients for Nile tilapia. Coefficients in each row with a different letter are significantly different $(P<0.05)$.

plant protein-rich products (46-86.2\%) in the diets of Nile tilapia [810]. Dry matter digestibilities in this study were generally lower than those reported for Nile tilapia elsewhere [13]. For example, the lower dry matter ADC of soybean in the present study could be explained by the higher crude fibre content of the product evaluated in this study of $69 \mathrm{~g} / \mathrm{kg}$, compared with $39 \mathrm{~g} / \mathrm{kg}$ in the study by Köprücü and Özdemir [13]. Other studies on fish have also indicated the negative correlation between crude fibre content and dry matter ADC [31-33]. In general, results of dry matter ADC can be used to estimate the amount of solid waste released to the environment and to help determine the environmental impacts of aquaculture production [7,32].

Generally, the protein quality of dietary ingredients is one of the leading factors (apart from palatability) affecting fish performance and protein digestibility (digestible protein) is the first measure of its availability to fish. Protein quality of dietary protein sources depends on the amino acid composition and their digestibility. In the present study, the values obtained for protein digestibility for SBC corroborate previous findings $(87.4 \%-96.2 \%)$ for soybean meal in tilapia diets $[8,10,12,13,24,34]$. Protein digestibility of test ingredients LSC $(62.4 \%)$ and NSC (72.6\%) for Nile tilapia in this study was lower than the reported digestibility coefficients of various other oilseed meals for this species. For example, reported APD in tilapia were $78.5 \%$ for cottonseed meal [34], 85\% for rapeseed meal [12], 77.6\% for peanut meal, $77.8 \%$ for canola meal, and $84 \%$ for de-gossypoled cottonseed meal [8].

Lower values of LSC protein digestibility in this study could be explained by other dietary factors present in plant protein products such as: i) suboptimal amino acid balance [24]; ii) presence of antinutritional factors [35]; and iii) inadequate levels of energy in linseed meals [36]. Plant products, especially oilseed cakes, usually have poor amino acid profiles and a certain amount of antinutritional factors (ANFs) which could affect nutrient utilization and, consequently, animal growth performance in different degrees depending on the type and amount of the compound [5,20-23]. Although linseed meal has been reported to have one of the best amino acid profiles after soybean meal and the composition fulfills the requirements of amino acid for Nile tilapia, the biological availability of amino acids in linseed to tilapia is less [37]. Linseed contains mucilage (5-8\%) which has a large capacity to bind to water and increases intestinal viscosity, thus reducing nutrient digestibility [38]. Major antinutritional factors known to be present in linseed include: cyanogens, phytic acid, tannins, estrogenic factors, antithiamine factor and antipyridoxine factor [5]. For example, the ANF phytic acid has the ability to non-selectively bind to proteins, carbohydrates and minerals (divalent cationssuch as $\mathrm{Ca}^{2+}, \mathrm{Fe}^{2+} \mathrm{Mg}^{2+}$ ) and inhibit activities of a number of digestive enzymes such as pepsin, trypsin and alpha-amylase [35].

The lower protein digestibility coefficients obtained for the two test ingredients (LSC and NSC) in the present study could not only be attributed to the ANFs but also to the higher levels of crude fibre that interfere in protein digestion of the diets that contain LSC and NSC. Previous studies $[12,31]$ indicated that feeds with high crude fibre contents have poor nutrient digestibility due to reduced enzymatic access to potential substrates or due to the direct interaction between crude fibre components and the digestive process. Fibre levels as high as $8-12 \%$ are tolerated by most fish, but such levels often result in growth depression $[39,40]$. Fish fed diets high in indigestible fibre increase their feed intake and gastric evacuation time, but the extent to which fish can compensate in this manner is limited [41].

ADC values of fats in fish range from $85 \%$ to $95 \%$ when administered routinely either alone or in a mixed diet [42]. Reported fat digestibility in other species ranged from $70 \%$ to $90 \%[12,43]$ and similar values were found for tilapia in this study (78.8-81.3\%). The ADCs of energy (53.6\%-85.9\%) in test ingredients for Nile tilapia in this study are generally in agreement with that reported (39-89\%) and (54.8-92.1\%) by Sklan et al. [12] and Köprücü andÖzdemir [13], respectively. Variation in apparent GE digestibility coefficients of ingredients in this study followed the same trend as that of protein and DM digestibility.

In the present study all three oilseed cakes tested proved valuable as protein sources in the diets of Nile tilapia as indicated by their ADCs. However, best values were observed for SBC. NSC, which was less than half the cost of SBC, appeared to be a good protein feed ingredient for Nile tilapia diets on balance in terms of overall nutrient composition and acceptable digestibility coefficients despite the highest crude fibre content. The LSC generally performed poorly, although it contained $310 \mathrm{~g} / \mathrm{kg} \mathrm{CP}$. The nutrient and energy digestibilities were very low except for lipid digestibility. It seems that the ANF present in linseed cake may be responsible for the low ADC values. However, further research is required to establish the effect of dietary inclusions of LSC and NSC on productivity and on the various potential methods of increasing their utilization in fish diets before considering these ingredients in production feeds. The results of this digestibility study should contribute towards a better understanding of the nutrition of this species, especially in the grow-out stages.

\section{Acknowledgments}

This work was financed by the Department for International Developmen (DFID) from Development Partnership for Higher Education (DeIPHE) project.

\section{References}

1. Glencross BD, Booth M, Allan GL (2007) A feed is only as good as its ingredients - a review of ingredient evaluation strategies for aquaculture feeds. Aquaculture Nutrition13: 17-34

2. Ng WK, Romano N (2013) A review of the nutrition and feeding management of farmed tilapia throughout the culture cycle. Reviews in Aquaculture 5: 220-254.

3. El-Sayed AFM (2004) Protein Nutrition of Farmed Tilapia: Searching for Unconventional Sources.

4. Hardy RW (2010) Utilization of plant proteins in fish diets: effects of global demand and supplies of fishmeal. Aquaculture Research 41: 770-776.

5. Tacon AGJ (1997) Fishmeal replacers: review of antinutrients within oilseeds and pulses-a limiting factor for the aquafeed Green Revolution?

6. Hecht T (2007) Review of feeds and fertilizers for sustainable aquaculture development in sub-Saharan Africa. Study and analysis of feeds and fertilizers for sustainable aquaculture development, Rome.

7. Allan GL, Parkinson S, Booth MA, Stone DAJ, Rowland SJ, et al. (2000) Replacement of fish meal in diets for Australian silver perch, Bidyanusbidyanus I. Digestibility of alternative ingredients. Aquaculture 186: 293-310.

8. Zhou QiC, Yue YiR (2012) Apparent digestibility coefficients of selected feed ingredients forjuvenile hybrid tilapia, Oreochromis niloticus $\times$ Oreochromisaureus. AquacultureResearch 43: 806-814. 
Citation: Geremew A, Getahun A, Rana K (2015) Digestibility of Soybean Cake, Niger Seed Cake and Linseed Cake in Juvenile Nile Tilapia, Oreochromis niloticus L. J Aquac Res Development 6: 333. doi:10.4172/2155-9546.1000333

9. Guimaraes IG, Pezzato LE, Barros MM, Tachibana L (2008) Nutrient digestibility of cereal grain products and by-products in extruded diets for Nile tilapia. Journal of the World Aquaculture Society 29: 781-789.

10. Fontainhas-Fernandes A, Gomes E, Reis-Henriques MA, Coimbra J (1999) Replacement of fish meal by plant proteins in the diet of Nile tilapia: digestibility and growth performance. Aquaculture International 7: 57-67.

11. El-Saidy DMSD, Gaber MMA (2003) Replacement of fish meal with a mixture of different plant protein sources in juvenile Nile tilapia, Oreochromis niloticus (L.) diets. Aquaculture Research 34: 1119-1127.

12. Sklan D, Prag T, Lupatsch I (2004) Apparent digestibility coefficients of feed ingredients and their prediction in diets for tilapia, Oreochromisniloticus $\mathrm{x}$ Oreochromisaureus (Teleostei, Cichlidae). Aquaculture Research 35: 358-364.

13. Köprücü K, Özdemir Y (2005) Apparent digestibility of selected feed ingredients for Nile tilapia (Oreochromis niloticus). Aquaculture 250: 308-316.

14. El-Sayed AFM (1999) Alternative dietary protein sources for farmed tilapia, Oreochromis spp. Aquaculture179: 149-168.

15. Lovell T (1998) Nutrition and feeding of fish. Kluwer Academic Publishers, Massachusetts.

16. Tadelle D, Nigusie D, Alemu Y, Peters KJ (2002) The feed resource base and its potentials for increased poultry production in Ethiopia. World's Poultry Science Journal 58: 77-87.

17. Assaminew K, Waidbacher $\mathrm{H}$, Zollitsch W (2012) Proximate composition of selected potential feedstuffs for small-scale aquaculture in Ethiopia. Livestock Research for Rural Development 24

18. Getinet A, Sharma SM (1996) Niger. Guizotiaabyssinica (L. f.) Cass Promotingthe conservation and use of underutilized and neglected crops. 5 . Institute of Plant Genetics and Crop Plant Research, Gatersleben/International Plant Genetic Resources Institute, Rome.

19. Wijnands J, Biersteker J, Hiel R (2007) Oilseeds business opportunities in Ethiopia. Ministry of Agriculture, Nature and Food Quality, Netherlands.

20. Hasan MR, Macintosh DJ, Jauncey K, (1997) Evaluation of some plant ingredients as dietary protein sources for common carp (CyprinuscarpioL.) fry. Aquaculture 151: 55-70

21. Mukhopadhyay N, Ray AK (2001). Effects of amino acid supplementation on the nutritive quality of fermented Linseed meal protein in the diets for rohu, Labeorohita, fingerlings. J Appllchthyol 17: 220-226.

22. Mukhopadhyay N, Ray AK (2005) Effect of fermentation on apparent total and nutrient digestibility of Linseed, Linumusitatissimum, meal in rohu, Labeorohita, fingerlings. Actaichthyologicaetpiscatoria 35: 73-78.

23. Latif KA, Alam MT, Sayeed MA, Hussain MA, Sultana S, et al. (2008) Comparative study on the effects of low cost oil seed cakes and fish meal as dietary protein sources for Labeorohita (Hamilton) fingerling. Univ j ZoolRajshahiUniv 27: 25-30.

24. National Research Council (NRC) (1993) Nutrientrequirementsoffish. National Academic Press, Washington DC, USA.

25. Cho CY, Cowey CB, Watanabe T (1985) Finfish Nutrition in Asia. Methodological approaches to research and development. International Development Research Centre, Ottawa.
26. Cho CY, Slinger SJ, Bayley HS (1982) Bioenergetics of Salmonid fishes: energy intake, expenditure and productivity. CompBiochemPhysiol 73: 25-41.

27. Divakaran S, Leonard GO, lan PF (2002) Note on the methods for determination of chromic oxide in shrimp feeds. J Agric Food Chem 50: 464-467.

28. AOAC (Association of Official Analytical Chemists) (1995) Official methods of analysis AOAC, Arlington, Virginia, USA.

29. Bureau DP, Harris AM, Cho CY (1999) Apparent digestibility of rendered anima protein ingredients for rainbow trout (Oncorhynchusmykiss). Aquaculture 180 345-358.

30. Zar JH (2010) Biostatistical analysis. Prentice-Hall, Inc, New Jersey, USA

31. Maina JG, Beames RM, Higgs D, Mbugua PN, Iwama G, et al. (2002) Digestibility and feeding value of some feed ingredients to tilapia Oreochromisniloticus (L.) Aquaculture Research 33: 853-862.

32. Guimaraes IG, Pezzato LE, Barros MM, Fernandes RDN (2012) Apparen nutrient digestibility and mineral availability of protein-rich ingredients in extruded diets for Nile tilapia. R Bras Zootec 41: 1801-1808.

33. Asad F, Rehman T, Qureshi NA, Tahir N (2013) Estimation of apparent digestibility coefficient of plant feed ingredients (soybean and sunflower meal) for LabeoRohita. American Journal of Biomedical and Life Sciences 1: 8-11.

34. Guimaraes IG, Pezzato LE, Barros MM (2008) Amino acid availability and protein digestibility of several protein sources for Nile tilapia, Oreochromis niloticus.Aquaculture Nutrition.14: 396-404.

35. Liener IE (1994) Implications of antinutritional components in soybean foods. Critical Reviews Food Science and Nutrition 34: 31-67.

36. El-Saidy DMS, Gaber MMA (2001) Linseed meal- its successful use as a partial and complete replacement for fish meal in practical diets for Nile tilapia Oreochromis niloticus.

37. Hanafy MA (2006) Effect of replacement of soybean meal by linseed meal on growth performance, and body composition of Nile tilapia Oreochromisniloticus (L) cultured in concrete ponds. Egypt J AquatBiol\& Fish 10: 185-200.

38. Fedeniuk RW, Biliaderis CG (1994) Composition and physicochemica properties of linseed (Linum usitatissiumum) mucilage. J Agric Food Chem 42 240-247.

39. Edwards DJ, Austreng E, Risa S, Gjedrem T (1977)Carbohydrate in rainbow trout diets. I. Growth of fish of different families fed diets containing different proportions of carbohydrate. Aquaculture 11: 31-38.

40. Leary DF, Lovell RT (1975) Value of fibre in production diets for channel catfish. Trans Am Fish Soc 104: 328-332.

41. Leenhouwers JI, Ortega RC, Verreth JAJ, Schrama JW (2007) Digesta characteristics in relation to nutrient digestibility and mineral absorption in Nile tilapia (Oreochromisniloticus L.) fed cereal grains of increasing viscosity. Aquaculture 273: 556-565

42. Aksnes A, Opstvedt J (1998) Content of digestible energy in fish feed ingredients determined by the ingredient-substitution method. Aquaculture 161: 45-53.

43. Lupatsch I, Kissil GW, Sklan D, Pfeffer E (1997) Apparent digestibility coefficients of feed ingredients and their predictability in compound diets for gilthead seabream, Sparusaurata L. Aquaculture Nutrition 3: 81-89. 